\title{
Are There Ideological Aspects to the Modernization of Agriculture?
}

\author{
Egbert Hardeman · Henk Jochemsen
}

Accepted: 30 July 2011/Published online: 19 August 2011

(C) The Author(s) 2011. This article is published with open access at Springerlink.com

\begin{abstract}
In this paper we try to identify the roots of the persistent contemporary problems in our modernized agriculture: overproduction, loss of biodiversity and of soil fertility, the risk of large animal disease, social controversies on the lack of animal welfare and culling of animals, etc. Attention is paid to the historical development of present-day farming in Holland as an example of European agriculture. We see a blinkered quest for efficiency in the industrialization of agriculture since the Second World War. Key factor is the cultural mindset at the foundation of our modern society, originating from the ideas of the enlightenment. It makes people vulnerable to ideologies, causing them to focus on a certain goal without considering the consequences. Due to the overemphasis on efficiency, modern industrial agriculture has never been comfortably embedded in its ecological and social context, and as a result displays the characteristics of an ideology. The cause of the inability to solve today's problems is therefore deeper than simply a failure to apply the right mix of standard remedies. Unless stakeholders in farming start to counter this very one-sided approach to efficiency, modernization will continue to cause all kinds of friction. The implications of the results for agricultural policy, farming and further research are discussed.
\end{abstract}

Keywords Agriculture $\cdot$ Culture $\cdot$ Modernization · Ideology $\cdot$ Enlightenment

\section{Introduction}

After lying quiet for many decades, foot and mouth disease (FMD) hit Europe with vengeance in 2001. With the transportation of animals, the virus again spread

\footnotetext{
E. Hardeman · H. Jochemsen $(\bowtie)$

Wageningen University and Research Centre, Hollandseweg 1, $6706 \mathrm{KN}$ Wageningen,

The Netherlands

e-mail: Henk.jochemsen@wur.nl
} 
through Western European countries, including the Netherlands. In that country, the culling of 260,000 biungulates that followed was a traumatic event for many Dutch farmers as well as for many other people: why did the Government act so harshly towards these animals and their owners? Why had these animals not been vaccinated? and at a more general level: why were these animals simply treated as production machines without intrinsic value? (See e.g., Korthals 2004; Van der Ziel 2008).

This FMD crisis painfully demonstrated the many misconceptions that exist regarding agriculture amongst both the Government and the people generally. But above all, it highlighted the problems and controversies in modern agriculture. Other examples are the debate on genetic modification, the manure surplus, the alleged tension between agriculture and nature, and so on. Many authors have debated why modern agriculture is beset with so many serious drawbacks and not only the number of issues is worrying, but also their apparent insolubility. Problems often seem to have a solution, yet these solutions in turn often bring new problems.

We investigate this problematic side of contemporary agriculture. How can we deal structurally with this issue, and arrive at better farming practices? To answer this question, we develop a three-stage argument. First, we briefly deal with the history of modern agriculture and identify a number of factors and trends that typify its basis and character. For practical reasons we concentrate on the Netherlands, but regard the developments in this country as a reflection of what is happening in the industrialized world generally. For some readers this may be pretty obvious material, but to enable readers who are less acquainted with this subject we begin our argument with some widely published historical notes since those historical processes harbour the root of the developments highlighted in this paper. Secondly, we pay attention to the deeper level of cultural-ethical motives behind the industrialization of agriculture. We do so since, in our view, we must go beyond general policy solutions to reveal the roots of the tensions and the resistance to solutions. This analysis will result in a useful framework for identifying the origin of many contemporary problems of industrial agriculture. Finally, we arrive at new conclusions regarding the origin of the structural problems, which may provide the key to better agriculture.

\section{Notes on the Recent History of Agriculture}

Around 1850, a predominantly agricultural era in Western Europe came to an end (Van Bruchem and Visser 2004). Dutch farmers were confronted with falling prices for their products, while at the same time the cost of labor, water management, and taxes increased (all due to several wars). Technology was introduced, using the possibilities created by the Industrial Revolution. As a result, the volume of the food production was no longer restricted by human labor and hence by the growth rate in the population (Bieleman 2008).

Since then, developments in agriculture have accelerated. Factors that should be mentioned are the introduction of chemical fertilizers and the rapid expansion of means of transport (Schelhaas 2003). Farming transformed rapidly into a stock- 
breeding activity focused on exports (Bieleman 2008). This already led to the first worldwide crisis in 1878, as demand did not meet the supply of cheap food products (Van Bruchem and Visser 2004). This consistent tendency to over-produce was a feature of agriculture up to the Second World War and life for farmers remained tough.

After World War II, agricultural activities were diligently resumed. The history of the decades following World War II can be summarized into several general developments. Because these are widely recognized, they need only be mentioned briefly. The first is mechanization: the process of replacing human work forces and techniques with machines and technological procedures (for an overview, see Priester 2000). The second salient development is intensification, in this case meaning the increase in production per hectare or per animal. The third development is specialization, where farms focus only on one type of crop or activity, e.g., dairying, pig-keeping, poultry, or maize.

The leading role of science and technology is the fourth development to be mentioned. Agronomic research has focused on the increase of productivity per unit of labor through the use of new technologies and capital. Hence it underliesamong others-developments in plant breeding, resistance to disease, artificial insemination, and the feed conversion rate (Bieleman 2000b, 2008). The final development to be mentioned is the increase in the scale of farming, which has been vigorously stimulated by Government and the education of farmers. Four subprocesses can be distinguished: re-allotment, the introduction of non-land-based farms, the growth in their size, and the decrease in their number (Van Bruchem and Visser 2004; Bieleman 2008).

\section{Trends Behind the Industrialization of Agriculture}

This very concise description of the developments in Dutch agricultural history since the Second World War can be summarized in one word: industrialization. The developments described are closely interrelated. More specific, common trends can be identified. Some of these trends have given rise to the developments mentioned earlier. Others can be seen rather as their result. In this chapter we identify the most important of them. Note that in actual fact, the distinction between the trends is not always as clear as described here. They often overlap and occur simultaneously.

\section{Decreasing Marginal Return}

Many changes in modern agriculture take place in a context of decreasing revenues and increasing costs (van Bruchem and Visser 2004). Although market prices always fluctuate in each sector of the economy, agriculture is characterized by long periods of low prices and short periods of high prices (Schelhaas 2003). At the same time, the costs of necessary inputs in agriculture keep pace with general inflation: feed, labor, land, and machine prices have increased constantly. Hence, farmers seemed to have no alternative but to participate in the developments of mechanization, intensification, and specialization in order to maintain a reasonable 
income. Dutch farmers' income is clearly below the national average (LEI 2007), and agricultural income per manpower unit is expected to continue to fall (LEI 2010).

\section{The Government's Major Role}

The Government fulfils an essential role in agricultural industrialization; some even argue that it would never have developed the way it did without explicit government intervention (Van der Ploeg 1999). The Government forcefully restored agriculture and its related infrastructure following their destruction in by World War II. For example, funds such as the Borgstellingsfonds (Security Fund) stimulated a rapid mechanization (Bieleman 2008). But the Government planned a more profound change of the very structure of agriculture, adopting a top-down approach of laws and regulations (Visser 2010). Its mission was to ensure a stable and sufficient food supply at a fair consumer price, combined with a reasonable income for farmers (Van Bruchem and Visser 2004; Visser 2010). This meant a guiding role for the Government.

The desired increase in productivity - in the eyes of the Dutch governmentrequired a large, stable export market, achieved by setting up extensive cooperation between European countries (Massink and Meester 2002). Soon, the European agricultural sector became not only self-sufficient, but a net exporter and created substantial, problematic surpluses (see fifth trend). At the same time, Government is seen in its stimulating role with regard to up-scaling, the influence of science, specialization, and intensification by recourse to the threefold remedy of research, information, and education (Bieleman 2008).

\section{Rationalization}

In this context, rationalization may be defined as the introduction of goal-rational methods in a process previously based on accumulated experience, ultimately to achieve greater efficiency in agriculture. It is therefore an essential characteristic of industrialization, evidencing the particular influence of science and technology (Van der Ploeg 1999). All measures taken by Government to change the structure of agriculture are informed with the desire for rationalization (Bieleman 2000a). This is clearly shown by the clause "to increase agricultural productivity by promoting technical progress and by ensuring the rational development of agricultural production" in article 39 of the Treaty of Rome (1957). In American literature on agriculture this is sometimes referred to as "productivism" (Buttel 2005, p. 276).

\section{Uniformity}

Under pressure from the economic pincer movement and driven by rationalization, agricultural activities became more and more uniform. Because farmers saw rationalization as the sole potential for the future, they used the same scientific data when seeking solutions. This made "agricultural science a globalizing factor" (Van der Ploeg 1999, p. 216). Specialization automatically brought uniformity, and 
farmers did not see much opportunity for serious differentiation. All this resulted in highly impoverished diversity in present day agriculture compared with the early twentieth century.

\section{Structural Problems}

Modern agriculture seems almost irrevocably to be bound up with problematic sideeffects; this is the fifth trend. Overproduction is a major problem that has already been with us for decades (Klijnhout 1965; Schelhaas 2003). ${ }^{1}$ A second major issue is animal welfare: animals are being reduced to an economic production factor whose intrinsic value is not respected (Korthals 2004; Massink and Meester 2002; Paarlberg 2009). Other issues that appear to resist a solution are the manure surplus, the debate on genetic modification, and the culling of animals, for example during epidemics of swine fever and FMD.

\section{The Gap Between Agriculture and Society}

In modern times, too often there seems to be a discrepancy between the ideas that exist in society about what the farming sector looks like and the functions and reality of this sector. Interestingly enough, this gap between farmers and nonfarmers has not been taken sufficiently seriously as a useful approach to the analysis of modern agriculture. Van der Ploeg (1999) coined the concept of the virtual farmer in this connection, representing an imaginary view of farmers in the public mind. People wrongly assume that farmers act as these virtual counterparts.

Two versions of this virtual farmer can be distinguished. Firstly a homo economicus as seen by the policymakers, suggesting a farmer interwoven with the general economy and acting as economical as all other agents in the market (Van der Ploeg 1999; Treaty of Rome 1957, article 39.2). However, agriculture is a distinct social-economic sector with its own specific characteristics (Korthals 2004). The second virtual farmer lives in the perception of the town dweller as an oldfashioned, relatively primitive person without direct visible impact on food production (Korthals 2004; van Bruchem and Visser 2004). Three reasons for the existence of the virtual farmer can be distinguished: extensive division of labor (hardly anyone is now involved in primary food production), urban migration (farming has disappeared from view), and "technification" of agriculture (farming became hard to understand). For example, many no longer choose to consider whether practices in agriculture might be immoral (Williams 2008).

\section{A Cultural-Ethical Theory of Ideology}

So far, we have looked at the industrialization of Dutch agriculture in a historical perspective. The industrialization started particularly as a project after the Second

\footnotetext{
${ }^{1}$ Whether this overproduction is necessarily caused by industrialization has been debated over and over again, and we leave this issue to the reader. For our purposes it is enough to establish a correlation.
} 
World War, and radically transformed agriculture. At the same time, as already pointed out in the terms of reference, contemporary agriculture is a can of worms. Experts, both policy-makers and researchers have tried and are still trying to find solutions. And despite all efforts on a global scale, they have not managed to find effective and workable solutions. Generally speaking, the solutions used usher in a paradox: often they reinforce or aggravate the problems they should solve, or create new and sometimes worse problems. This suggests that to a certain degree, we have no control over our problems and solutions. How did this phenomenon arise?

In this paper, we argue that there is a relationship between the cultural mindset behind the industrialization of agriculture and the stubbornness of its problems. Our analysis starts with the Era of Enlightenment in Europe, occurring in the eighteenth century and roughly ending with the French Revolution. This philosophical, cultural, and political movement has been observed and interpreted in many different ways. It comprised a lengthy, consecutive series of interlocking and sometimes warring intellectual debates and writing by thinkers of all kinds (see: Outram 2005). Broadly, there is agreement that its core content consisted of two aspects: a critical questioning of traditions, customs, morals, and institutionalized religion; and a constructive search for new, rational knowledge and science pursuing such ideals as control of reality, social justice, equality, and democracy.

The criticism of medieval religion and its goals led to the search for an alternative meaning of life, new norms and values, etc. This change has been of vital importance to the way people value life itself, their purpose in life and their whole environment. Secular thinking has begun to impinge in places where the public impact of traditional Christianity has declined. It has been driven from the start by the desire to achieve a new, rational social structure. That meant, amongst other things, that the world came to be seen as a structure of many building blocks without intrinsic value, that people can rearrange in whatever they want.

So far, we have presented nothing new; this is all broadly accepted knowledge. But continuing our analysis, we want to borrow from the insights of the Dutch economist Goudzwaard et al. (2007). These writers are trying to find an explanation for the world's contemporary global crises such as worldwide poverty, environmental degradation, and widespread terrorism. They consider the thoughts of the French Enlightenment philosopher Destutt de Tracy (1754-1836) on modern ideologies as the key to clarifying the crises concerned. De Tracy was fully involved in developments surrounding the French Revolution and its desire for radical social change. He mused on how education could lead children to copy the ideals of the French Revolution - freedom, equality, and brotherhood - as self-evident truths. He reasoned that, because it would need to change the whole system of ideas, values, and norms, a discipline or science was needed to study the origin and development of human ideas. He coined the term ideology for this. The knowledge obtained from this science can be directly applied to changing one's mindset. As Goudzwaard et al. put it, "here for the first time we encounter a deliberate political attempt to systematically regulate or manipulate people's currently held ideas in order to achieve certain societal ends" (2007, p. 33). This became the present-day meaning of the word "ideology". 
Undeniably, ideologies existed centuries before the French Revolution, although not called such. These "classical" ideologies have three common characteristics. Firstly, they have an absolutized end with a corresponding narrowing of focus. Secondly, they require a redefinition of currently held values, norms and ideas "to such an extent that they legitimize in advance the practical pursuit of the predetermined end" (Goudzwaard et al. 2007, p. 33). Finally, they take this absolutized objective as a sole criterion for the choice of methods: the end justifies all means.

Modern ideologies - namely ideologies that emerged after the Enlightenmentintroduce three additional aspects compared with classical ideologies. Firstly, they are all rational by nature and are systematically thought through (rationalization). Secondly, they have radical breadth and depth (radicalization). Thirdly, they pursue the most efficient possible use of all means (instrumentalization). Summarizing, modern ideologies became hardened and totalitarian. Remember that, in contrast to the religious goals that saw service in ideologies during the Middle Ages, a modern ideology introduces the novelty of pursuing a specific "earthly" objective as an absolute end. This was the direct result of the Enlightenment, because it removed religion and religious belief as the primary source of the experience of the meaning of life.

The latter conclusion is of vital importance to the reasoning of Goudzwaard and his colleagues. In their view, the Enlightenment not only changed the character of ideologies, but also enhances the vulnerability of people to ideologies. After all, if worldly ends replace the religious goals as the meaning-giving source, there is a high risk that people will impose quasi-religious traits on those ends (Goudzwaard et al. 2007, pp. 36-38). In other words, secular groups or societies more easily pursue a social goal in an ideological way, consciously or not. In practice, an important sign of this is the development of a certain narrow-mindedness, which means that people predominantly focus on the goal and particular methods for reaching it without paying serious attention to the influence this has on their environment. They see no alternative goal or methods, and believe that they should continue along the chosen path, even though the methods for achieving the goal seem to enhance current problems or create new ones.

This might result in an aggressive, political ideology that debases a whole society. Nazism (serving the realization of the Third Reich) and Soviet Communism (serving the victory of the working class) are two major examples from the twentieth century. But as the authors argue, the tendency towards ideology is not only found in such horrific, totalitarian systems. Numerous kinds of "mild," partial ideologies can be found in Western societies. Their character is such that they may never lead to mass murder and other horrific acts. The objective can even be reasonable and legitimate in itself. But they still show the features of a modern ideology: an absolutized end and a corresponding rational theory; a radical redefinition of values and norms; and an unrestricted, instrumental use of means to reach this end. For example, the authors argue that the survival of one's cultural identity has increasingly become an ideological end in itself, which is the explanation behind widespread ideological terrorism. It also provides an explanation of the fanaticism found in the protracted conflict in Palestine and the appearance of apartheid in South-Africa in the twentieth century. 
To clarify the above further, we include two examples of legitimate human purposes in our contemporary society that display ideological traits. The first is the pursuit of material wealth as discussed by Goudzwaard et al. Modern societies are convinced of an unquestioned need for economic growth as the solution in the war against human poverty, hunger, and unfulfilled basic needs. Especially in predominant neo-liberal thinking, the free market - a concept dating from the time of the Enlightenment-should be given free rein, and economic sectors and aspects should be subjected to the dynamics of supply and demand. This market mechanism is now the coordinator of economic activity and policy makers create social, legal, and financial space for the necessary technology. Money decides what is good or not for society.

This idea has produced impressive economic wealth and it would not be a problem were it not that "certain things in life cannot succumb to the dynamic forces of production" (Goudzwaard et al. 2007, p. 90). This applies, for example, to the environment. Leaving its management to the market results in numerous tensions between its actual and required capacity, both in the supply of raw materials and in waste disposal. Another example is the healthcare system, which in most wealthy countries is squeezed between the provision of comprehensive care and the desire for economic efficiency. But, even though the quest for material wealth has created many comparable major problems on a global scale, the growth of wealth continues to be seen as the solution to those problems: more wealth will ultimately help the poor and thus solve its own adverse effects. As Goudzwaard et al. show, this pattern of thinking exhibits traits of ideological narrow-mindedness.

The second example concerns technology, which is closely related to both material wealth and agricultural industrialization. Modern technology is dynamic and has expanded exponentially. This is not only true of physical machines and other products, but also of the encompassing science of technology. Ellul, one of the leading thinkers in the field of philosophy of technology, coined the (French) word technique to indicate "the totality of methods rationally arrived at and having absolute efficiency in every field of human activity" (Ellul 1964). Hence "technique" means any set of standardized methods used for a predetermined purpose, with physical mechanization as only one part of it (Young 1988). It is a means of control, which includes nature, the laws of nature, the environment and human limitations (Van der Laan 2004).

In the history of technology, two types or periods can be distinguished: traditional technology and modern technology resulting in 'technique' (Ellul 1964; Young 1988; Schuurman 2005). Traditional technology and techniques function in a traditional society, where they are subordinated to certain requirements such as religious prescriptions (Ellul 1992). The rules were more important than the tools, and efficiency was more than offset by stability. In other words, techniques were subordinated to the needs of cultural control (Roy 2005). Modern technology, however, arrived at the point when the traditional cultural bedrock disappeared, and in our present society there are essentially no limits to either the development of technology or to its goals (Schuurman 2005; Visser 2010). In this case, technology has the freedom to develop in every direction it wants and becomes a supposedly independent phenomenon. 
Four factors facilitate this process. Firstly, making life easier by implementing techniques has always appealed to humans but is especially tempting in our Western economy of seduction and being seduced (Van der Laan 2004). Secondly, there is something that Ellul called technological bluff: technology is seductive, but also often bluffs mankind by its amazing capacities (Ellul 1990). Technological bluff spreads the vague and general notion that technology is a sole and unique source of human improvement and progress (Son 2004). It makes people feel satisfied with a certain degree of technification. It can overwhelm people and the possibilities that a new technique offers often make people feel good. Thirdly we note there is always an interaction between a human being and his or her environment, including technology (VanderBurg 2004). And if technology has a strong influence on a person, that person may get the impression that his life is determined more by technology than vice versa. This creates a sense of autonomy of technology, a concept Ellul frequently works with (see on this point also Goudreau 2003). Fourthly, when a person depends largely on technology it is impossible to maintain a well-balanced assessment of technology (Furr et al. 2005; Schuurman 2005). Dependence on technology prevents an objective evaluation of its use and impact. Implementing techniques thus becomes more or less standard without a critical assessment.

All of this again reveals the traits of an ideology, and we should not refrain from using such a loaded word in this context. Roy even calls technology a modern religion, which points at the pseudo-religious role that people attribute to technique (Roy 2005). Does the phrase "new technology" not have a positive tone by definition? Only few people see the downside of technology and technical development as a possible threat to the quality of life (Schuurman 2005).

\section{Modernized Agriculture}

Given this cultural-ethical treatise, the question is: do similar ideological goal orientations underlie agriculture's most urgent problems? To answer this core question, the industrialization of agriculture must be tested for ideological traits. A number of characteristics should be tested for. Note that not all of them have to be equally visible but the more they are found the stronger the ideological character will be. Firstly, the three main characteristics of an ideology: (1) the presence of an absolutized end, with its narrow-mindedness (2) a reformulation of ideas, norms, and values and (3) the use of the chosen end as a sole criterion for the choice of method. Secondly, the three additional characteristics of a modern ideology: (1) a well-thought-out rational structure (2) a radical, and (3) a most efficient use of all resources involved. Thirdly, the belief that beyond the chosen means no alternatives can be found and, as a consequence, the tendency to solve the problems with the same means that caused these problems themselves in the first place. Fourthly and finally, the use of ideological or even religious terms by people involved in or talking about agricultural industrialization. ${ }^{2}$

\footnotetext{
${ }^{2}$ From now on we shall use the term modernization instead of industrialization, because to a certain degree it involves the cultural process behind the industrialization that we shall be testing.
} 
When studying the above-mentioned developments and trends in modern industrialized agriculture, we see one central aspect characteristic of all of them: the drive for efficiency in as many facets of agricultural life as possible. First and foremost, this was the desire and aspiration of the Dutch government directly after World War II, and a few decades later also of the European Community. Through structural policies, financial support, and encouragement of various modernization processes such as up-scaling and re-allotment, and the information institutions for farmers, attempts were made to boost any potential efficiency in agriculture.

Not surprisingly, this effort corresponds with the much broader trend in Western society towards economic efficiency as recorded in the previous section. This link is mainly due to the existence of the virtual homo economicus in the mindset of government officials and policymakers. The agricultural sector is seen and treated as a regular economic sector, as a modern industry (Paarlberg 2009). The key development is rationalization, exchanging the diversity in agriculture-existing both between geographical regions and different kinds of agriculture-for reasonable methods based on scientific knowledge. This reduction in diversity leads to considerable uniformity (Jochemsen 2008). The knowledge institutions for farmers function as pivotal bodies for policy transfer to the farming community.

There certainly is a positive relationship between the modernization of agriculture and overall economic growth in the long term (Self and Grabowski 2007). But, as already stated, agriculture fundamentally deviates from other sectors of the economy in its character, although whether this is still visible after so many decades of industrialization is open to question (Schelhaas 2003; for a detailed discussion see the contribution of Meester in Silvis 2004). Van der Ploeg (1999) elaborates on this and argues that farmers consciously evade the logic of markets for the sake of their own existence. Unfortunately, this difference between virtual and real farmers remains stubbornly intact. That should not surprise us, since the rationalization is spearheaded in the Treaty of Rome itself.

This conclusion is not only hindsight. Already in 1965, Klijnhout noted that the purpose of EC agriculture is "concentrated, specialized modern agriculture, fast and efficient," which can only be achieved by regarding agriculture as a "total industrial activity" (Klijnhout 1965, p. 27). Since the beginning of modernization, its core has never changed. All these developments indicate that agricultural efficiency has become an absolutized objective. The latter conclusion is aptly expressed by Van der Ploeg (1999). He calls the transformation of farming practice "to a new, scientifically defined optimum" the modernization project (p. 262). This project was first introduced by Government as a proposal but later increasingly portrayed as an inevitable process: it is the logical, if not law-like unfolding of the future (see also Visser 2010). It was said to be the only solution to escape the pincer movement of decreasing income and increasing costs. However, one may seriously wonder whether the market really forces companies to specialize and to increase their scale (Korthals 2004). Because, certainly, there are a number of alternative responses to the threat of farmers' reducing income (Van der Ploeg 1999, p. 281).

To state that norms and values in society are consciously changed to legitimize the search for efficiency in agriculture may sound exaggerated. It seems unfair to claim that the Dutch government actively and systematically manipulated attitudes 
and beliefs as to what efficiency in agriculture should be. Yet the Government radically transferred its objectives through information and education to the farming sector. We repeat that the knowledge institutions in particular acted as government agents to promote the application of scientific knowledge. In his farewell speech in 1983, the Wageningen professor of Information Studies, Van der Ban, expressed his concern at the tendency to seek a solution to agricultural problems in a reduction of productivity (Van der Ban 1983). This remark is typical of the limited direction in which information was provided: increasing productivity by working more efficiently. The decreasing awareness of local circumstances on the part of individual officers enforced this trend towards rationalization and standardization (Visser 2010).

It is here that the role of technique and technification comes into play, as described in the previous chapter. For in agriculture, almost every efficiency improvement means implementing a new technique, often obtained through scientific knowledge. Rationality becomes an essential feature for all technical development (Ter Borg-Neervoort 1982). By presenting agriculture as "unfolding scientific laws," progress is made only in the use of more techniques and patterns of action as devised by scientists (Van der Ploeg 1999). As a result, country life is integrated in a technological treadmill (Marsden 1998). Specialization, intensification, "scientification," up-scaling and other modern developments are manifestations of this treadmill. and all of this corresponds perfectly with the modern cultural view behind the use of science and technology: because the world does not have given structures but is just a conglomerate of materials and building blocks, mankind can entirely rearrange it for its own benefit through science and technology (Goudzwaard et al. 2007, see also Jochemsen 2008; Van den Berg and Nijhoff 2009).

Is this easy acceptance of techniques surprising? No. Two remarks are in place here. Firstly, as already argued in section three, the seductive character of technology fits our Western culture. This is also true of farmers, especially because their income level is concerned. Secondly, an interesting aspect of technique is that in itself it does not entail any ethical boundary. As traditional techniques were embedded in the natural and cultural order, there was no demand for an ethics of technology (Schuurman 2005). However, despite the continual development and intrinsic dynamics of modern techniques, only relatively little attention is paid to the ethical side of technology in agriculture). This is probably largely due to labor specialization that accompanies modern technology. No-one feels responsible for the bigger project: everyone carries out his or her technical task and everything else is irrelevant or someone else's responsibility (Ellul 1992). Again, this indicates an ideology: we are no longer concerned about whether a technique should be implemented, but how this should be done most efficiently and safely.

Making agricultural practice more efficient was not only very rational by nature, but also thoroughly addressed. The Government not only wanted to guide the sector but to change Dutch agriculture. Especially in the seventies of last century, government intervention rapidly expanded, e.g., in re-allotment projects. This radicalism may be even better illustrated by new techniques on a small scale or in inconspicuous areas. Think of the Best Farming Practices, trying to influence the 
limited amount of steps left to farmers after all attempts to regulate mechanization. Or, look at poultry farming practices: the biological constraints on a chicken were a reason for inventing a more efficient way of machine breading to overcome this natural rhythm (Bieleman 2000c). A wide range of available means was used to pursue greater efficiency: grants, taxes, promotion funds, re-allotment and so on. Many of them have been criticized since their introduction, and have certainly not been continued at all costs. Yet it is remarkable that their introduction was accompanied by a degree of indifference or insensitivity to their impact on practical farming. This again indicates a narrowing of focus: searching only to achieve the goal and thus forgetting the nuance.

In addition to radical depth, the terminology sometimes used in connection with agricultural modernization is striking. Here a few illustrative examples will suffice. Cullather uses the term miracles of modernization in the title of his paper on the Green Revolution (2004). Also remarkable is Bieleman's use of words such as "impressive" and "spectacular" in his historical descriptions of agriculture (2000, 2008). Van der Ploeg concludes that the modernization project acquired "an aura of indisputability," and adds that "the penalty for sin was not long in coming." The message is all too clear (1999, p. 271). This pseudo-religious terminology confirms the ideological traits of the modernization project.

The quest for efficiency turns out to have caused serious problems for the agricultural sector. As previously concluded, the sector seems to be linked inextricably to problematic side-effects: overproduction, loss of biodiversity and of soil fertility, lack of animal welfare, risk of animal diseases because of the large concentration of animals on small areas, social controversy on the culling of animals etc. Many of them result from a blinkered view that did not give them serious thought since only the realization of the primary goal of efficiency counted. Let us illustrate this with an example. Standardization in agriculture led to genetic erosion and vulnerability to disease (Jochemsen 2008). To resolve these effects the main cause, standardization itself, is not addressed. Instead, the risk of more diseases is tackled by the extensive use of chemical pesticides. When these pesticides turned out to cause serious environmental problems themselves, a new technology was introduced: genetic engineering of plants to make them resistant, either to certain, presumably less toxic, pesticides or to the pest. But the use of genetic modification forces genetic erosion yet further. This spiral of problems and "solutions" shows that the use of modern techniques to deal with their deleterious side-effects has caused new problems to accumulate.

The troubles were even aggravated because the economic pressure exercised by Government on farmers results in a greater willingness of farmers to resort to unethical measures (James and Hendrickson 2008). That is why ethically unjustifiable practices have slowly entered into agriculture, further contributing to the accumulation of problems. That these practices only caused much debate and civil disagreement later on is closely linked to the virtual farmer concept (see "A Cultural-Ethical Theory of Ideology" section). Questionable consequences of the chosen methods are hard to observe and are spotted only after long delays (Visser 2010). 
So the inability to solve today's problems has a deeper cause than simply failure to apply the right mix of standard remedies. Because of the restricted view, the integration of new technologies into the various social and ecological contexts remains a major problem (for a thorough study on this point see Visser 2010). If many of these modernizations are introduced into daily farming life, it will continue to cause all kinds of friction. Farmers may constantly attempt to increase production, which is not always needed (Klijnhout 1965). Korthals concludes that ecological problems particularly originate from the confrontation of science and technology with its own drawbacks (2004). Introducing science and technology seems to lead to improvement, but over time, problems start to return. Many still believe that when it comes to increased agricultural production and efficiency, science has a duty to examine every opportunity without any limits to its implications (Jochemsen 2008). De Hoogh rightly comments on this one-sided development: "We learn by trial and error, but do we really learn?" (1991, p. 312).

\section{Discussion}

In this paper we have tried to identify the roots of the persistent contemporary problems in our modernized agriculture. By studying the historical development of present-day farming in Holland, we were able to identify the key factors. We realize that several of these historical trends and their concomitant problems were identified earlier, not least in American literature (e.g., Buttel 1986, 2005; Burkhardt 1988). However, by interpreting these developments in the broader context of the cultural movement of modernization and of the concept of ideology as developed by Goudzwaard et al. (2007) we are able to achieve new insights that may turn out to be fruitful in thinking about agriculture policy.

Attention should be paid to the cultural mindset at the base of our modern society. Summarizing the results, modern agriculture is problematic because since it came of age, it has never really been embedded in its ecological and social context. Post-war policymakers were extremely focused on making agriculture more efficient, spreading specific scientific findings amongst large groups of farmers.

This could happen because beliefs about the value of life and the environment changed due to the Enlightenment movement. From its rational point of view, nature is made up of material and energy with no intrinsic value and man is essentially free to modify the current arrangement. These beliefs would not necessarily have to led to problems. However, since Enlightenment thinkers considered religion a superfluous source of meaning of life, they proposed new "worldly" goals with their values as a replacement. This harbored the risk of people attributing quasi-religious traits to those ends. If this happens, the end becomes absolutized and an ideology is born. This pattern is also found in agriculture to a certain degree. In this article, we have identified striking indications of an ideological character to modern industrialized agriculture.

This supports Goudzwaard's hypothesis of the existence of mild ideologies in our Western society (2007). The pattern found in agriculture is not a self-contained phenomenon but must be seen in the broader social pursuit of material wealth. As explained in "Trends Behind the Industrialization of Agriculture" section, the latter has 
been loaded with an ideological character as well. To quote De Hoogh again: "I regard the strong influence of economic forces on the speed and direction of technological developments as a major factor, which may explain why agricultural technology has not only produced great wealth, but has also cast dark shadows" (1991, p. 310).

This very one-sided focus on efficiency as the road to higher agricultural production caused the stakeholders in power to ignore the need to embed their calculations in the farming context and that is problematic by definition, causing all kinds of tensions (cf. Weis 2010). We realize this topic is not very popular, not least because it puts the finger on the problematic side of our prized Enlightenment. Goudzwaard acknowledges this when, talking about such terms as ideology, he comments that these words sound not only terribly heavy but also miles removed from us and from our own world (Goudzwaard 1984, p. 25). People like Ellul also realized this (Ellul 1964; 1992). Nevertheless, in our view our search for solutions in agriculture should not be determined by what is popular but by what in practice proves to be correct. Therefore, we would like to encourage historians to study the development of our industrialized agriculture in a broad, independent way. This present article is a start, but unravelling the forces behind agricultural history is a very complex matter.

Since ideologies functions at the level of a cultural mind-set, countering an ideology starts with the essential step of becoming aware of its presence (Ellul 1992). It also means that a new relationship between and integration of agriculture, sustainability, environment, and ethics will be needed (Meester et al. 2005; Weis 2010). It must include the social consequences of the policy implemented (De Hoogh 1991; Jochemsen 2008), not least indicating renewed attention to the opinions of farmers themselves (Guehlstorf 2008; Visser 2010). This new ethical attitude should also pay critical attention to the assistance provided to Third World countries towards modernizing and rationalizing their agriculture, perhaps more for political than for ideological reasons (e.g., the Green Revolution, as described by Cullather (2004) and Hamblin (2009)). Three steps can be distinguished in order to arrive at a form of ecological agriculture: ${ }^{3}$ an ethical reorientation on society level, an effect of the latter on a personal level, and a supplemental governmental policy.

Firstly, an ethical reorientation is required in dealing with agricultural issues. The utilitarian cost-benefit analysis commonly used in the technical-rational decisionmaking process does not provide adequate results (Ter Borg-Neervoort 1982, Korthals 2004). A full discussion of such a new, fruitful ethical attitude to agriculture is beyond the scope of this present study. A good start may be found in the work of Van den Berg and Nijhoff (2009), who present an ethical framework as a reaction to scientific-technological control in agriculture. For a similar approach focusing on technology and technique, see Schuurman (2005). The ethical considerations made by Korthals on different issues in agriculture can be of additional value (2004). Finally, an interesting survey and analysis of many ethical concerns regarding agriculture is published by Thompson and Hannah (2008).

\footnotetext{
${ }^{3}$ We use the word ecological in its broader sense: a way of farming that is economically, environmentally and socially embedded in its local context (cf. Delind and Bingen 2008). This is an alternative to top-down centralized "science in farming" projects (Visser 2010). For this issue see also Woodhouse (2010) and De Schutter (2010).
} 
Secondly, such a reorientation should be further developed at a personal level, especially with regard to the responsibility of stakeholders in agriculture. Goudzwaard et al. (2007) gives three guidelines in this respect. The first is called the periscope guideline. Becoming aware of ideological tendencies, one often experiences difficulty in distancing oneself from them: the ideological perspective is so intertwined with daily life that there seems to be hardly an alternative. This limited view of reality can be remedied with a periscope: the ability to rise above the surface and take a broader view. Taking into account the meaning of values such as justifiability, sustainability, freedom, and solidarity may act like such a periscope.

The second guideline is represented by the image of a minesweeper. If one fights an enemy who lays mines, a counter-reaction can be to lay mines also. But a solution that is better in the long run is to send a minesweeper. Anyone who is faced with the consequences and problems of an ideology in agriculture should not attempt to fight it with comparable methods and procedures, but try to eliminate the "explosive" elements inherent in industrialized agriculture. The third guideline is called a rope-ladder. For an individual, fighting the ideological traits in agriculture may seem a hopeless battle, but it can be fought in the same way as climbing a rope ladder: step by step, hand by hand. Ultimately, one must go from problem to problem and by good solutions break the downward spiral.

Thirdly, apart from new social and personal ethical conduct, additional government policies are needed to ensure stakeholders act according to mutually agreed ethical guidelines. Those engaged in agricultural science and technology for business purposes will have to meet conditions forcing them to take other than commercial interests and values into account (De Hoogh 1991; Paarlberg 2009). Think of regulations on animal welfare: if laws exist accompanied by regular checks, companies will generally comply with the rules (Korthals 2004; Meijboom et al. 2009). Another example is policy to avoid further reduction in the world's biodiversity (Jochemsen 2008; Chappell and LaValle 2009). Many countries have already taken steps of this kind but have not yet changed the main direction of agriculture.

In addition to government interventions, other issues will also affect the success or failure of new ecological agriculture. Firstly, developments in farming are to a substantial degree shaped by future liberalization of the European agricultural market (Meester et al. 2005). Secondly, the organization of the food chain that begins with farmers and ends with consumers is of major importance (Van Otterloo 2000). This chain has changed significantly over past decades, especially with regard to power: it is no longer the producer who decides what is produced, but the retail trade and its customers. For a good analysis of the food chain and ensuing future scenarios, see Food Wars by Lang and Heasman (2004). An important role is assigned to possible regionalization of production and consumption (Meester et al. 2005; Jochemsen 2008). This will again raise the question whether demand from consumer markets does indeed force farmers to modernize (see also Weis 2010). After all, one may even wonder whether largescale industrialized agriculture is more productive than an ecological alternative (Woodhouse 2010; Visser 2010). 
Open Access This article is distributed under the terms of the Creative Commons Attribution Noncommercial License which permits any noncommercial use, distribution, and reproduction in any medium, provided the original author(s) and source are credited.

\section{References}

Bieleman, J. (2000a). De Landbouw en het Sociaal-economisch Krachtenveld (Agriculture and SocioEconomic Forces). In J. W. Schot, H. Lintsen, \& A. Rip (Eds.), Techniek in Nederland in de Twintigste Eeuw, Deel III: Landbouw en Voeding (pp. 13-21). Zutphen: Walburg Pers.

Bieleman, J. (2000b). Biotechniek-Inleiding (Bioengineering-Introduction). In J. W. Schot, H. Lintsen, \& A. Rip (Eds.), Techniek in Nederland in de Twintigste Eeuw, Deel III: Landbouw en Voeding (pp. 127-129). Zutphen: Walburg Pers.

Bieleman, J. (2000c). Dieren en Gewassen in een Veranderende Landbouw: de Legkippenhouderij (Animals and Crops in a Changing Agriculture: Poultry Layer Management). In J. W. Schot, H. Lintsen, \& A. Rip (Eds.), Techniek in Nederland in de Twintigste Eeuw, Deel III: Landbouw en Voeding (pp. 155-179). Zutphen: Walburg Pers.

Bieleman, J. (2008). Boeren in Nederland: Geschiedenis van de Landbouw 1500-2000 (Farming in the Netherlands: A History of Agriculture 1500-2000). Amsterdam: Uitgeverij Boom.

Burkhardt, J. (1988). Biotechnology, ethics, and the structure of agriculture. Agriculture and Human Values, 5(3), 53-60.

Buttel, F. H. (1986). Agricultural research and farm structural change: bovine growth hormone and beyond. Agriculture and Human Values, 3(4), 88-98.

Buttel, F. H. (2005). Ever since Hightower: The politics of agricultural research activism in the molecular age. Agriculture and Human Values, 22, 275-283.

Chappell, M. J. \& LaValle, L. A. (2009). Food Security and Biodiversity: Can We have Both? An Agroecological Analysis. Agriculture and Human Values, published online: 27 November 2009.

Cullather, N. (2004). Miracles of modernization: The Green Revolution and the Apotheosis of Technology. Diplomatic History, 28(2), 227-254.

de Hoogh, J. (1991). Agricultural Technology: for Better or for Worse? In J. de Hoogh (pp. 305-313). Werkgroep Landbouwpolitiek: Beschouwingen over Landbouweconomie en Landbouwpolitiek. Wageningen.

de Schutter, O. (2010). Report submitted by the Special Rapporteur on the right to food, Olivier DeSchutter. UN Human Rights Council, December 2010, Doc. A/HRC/16/49.

Delind, L. B., \& Bingen, J. (2008). Place and civic culture: Re-thinking the context for local agriculture. Journal of Agricultural and Environmental Ethics, 21, 127-151.

Ellul, J. (1964). The technological society. New York: Vintage Books.

Ellul, J. (1990). The technological bluff. Grand Rapids: Eerdmans.

Ellul, J. (1992). Het Verraad van de Techniek (The Betrayal of Technology). Dutch TV broadcast by IKON on October, 8, 1992.

Furr, P. F., Ragsdale, R., \& Horton, S. G. (2005). Technology's non-neutrality: Past lessons can help guide today's classrooms. Education and Information Technologies, 10(3), 277-287.

Goudreau, K. A. (2003). Habermas on purposive-rational action: A contribution to the understanding of Ellul's technique. Bulletin of ScienceTechnology and Society, 23(3), 174-179.

Goudzwaard, B. (1984). Idols of our time. Illinois: Inter-Varsity Press.

Goudzwaard, B., Van der Vennen, M., \& van Heemst, D. (2007). Hope in troubled times: A new vision for confronting global crises. Grand Rapids: Baker Academics.

Guehlstorf, N. P. (2008). Understanding the scope of farmer perceptions of risk: considering farmer opinions on the use of genetically modified (GM) crops as a stakeholder voice in policy. Journal of Agricultural and Environmental Ethics, 21, 541-558.

Hamblin, J. D. (2009). Let there be light... and bread: The United Nations, the Developing World, and Atomic Energy's Green Revolution. History and Technology, 25(1), 35-48.

James, H. S., \& Hendrickson, M. K. (2008). Perceived economic pressures and farmer ethics. Agricultural Economics, 38, 349-361.

Jochemsen, H. (2008). An ethical assessment of cisgenesis in breeding late blight resistant potato. Potato Research, 51, 59-73. 
Klijnhout, C. C. (1965). Moderne Landbouw-politiek (Modern Agricultural Politics). Amsterdam/ Brussel: Agon Elsevier.

Korthals, M. (2004). Before dinner: Philosophy and ethics of food. Dordrecht: Springer.

Landbouw Economisch Instituut. (2007). Landbouw-Economisch Bericht 2007 (Agricultural Economic Report 2007). The Hague: LEI.

Landbouw Economisch Instituut. (2010). Landbouw-Economisch Bericht 2010 (Agricultural Economic Report 2010). The Hague: LEI.

Lang, T., \& Heasman, M. (2004). Food wars: The global battle for mouths. Minds and Markets. London/ Sterling: Earthscan.

Marsden, T. (1998). Agriculture beyond the Treadmill? Issues for Policy, Theory and Research Practice. Progress in Human Geography, 22(2), 265-275.

Massink, H. F., \& Meester, G. (2002). Boeren bij Vrijhandel: De Nederlandse Agrosector bij Handelsliberalisatie en EU-uitbreiding: een Verkenning (Farming and Free Trade: the Dutch Agribusiness in Trade Liberalization and EU Enlargement: an Exploration). The Hague: LNV.

Meester, G., Oskam, A., \& Silvis, H. (2005). EU-beleid voor Landbouw, Voedsel en Groen: van Politiek naar Praktijk (EU Policy on Agriculture, Food and Greenery: From Policy to Practice). Wageningen: Wageningen Academic Publishers.

Meijboom, F. L. B., Cohen, N., Stassen, E. N., \& Brom, F. W. A. (2009). Beyond the prevention of harm: Animal disease policy as a moral question. Journal of Agricultural and Environmental Ethics, 22, 559-571.

Outram, D. (2005). The enlightenment. Cambridge: University Press.

Paarlberg, R. (2009). The Ethics of modern agriculture. Society, 46(1), 4-8.

Priester, P. R. (2000). Boeren met Machines (Farming with Machines). In J. W. Schot, H. Lintsen, \& A. Rip (Eds.), Techniek in Nederland in de Twintigste Eeuw, Deel III: Landbouw en Voeding (pp. 65-125). Zutphen: Walburg Pers.

Roy, R. (2005). Scientism and Technology as Religions. Zygon, 40(4), 835-844.

Schelhaas, H. (2003). Liberalisering in de landbouw: Mogelijkheden en grenzen (Liberalization in Agriculture: Opportunities and Limits). Wageningen Academic Publishers (dissertation), Wageningen.

Schuurman, E. (2005). The technological world picture and an ethics of responsibility. Sioux Center: Dordt College Press.

Self, S., \& Grabowski, R. (2007). Economic Development and the Role of Agricultural Technology. Agricultural Economics, 36, 395-404.

Silvis (red.), H. J. (2004). Landbouwbeleid: Waarom ook al weer? (Agricultural Policy: why again?). The Hague: LEI.

Son, W. C. (2004). Reading jacques Ellul's the technological bluff in context. Bulletin of ScienceTechnology and Society, 24(6), 518-533.

Ter Borg-Neervoort, M. (1982). Innovatie tot in Eeuwigheid: het Geloof in de Technische Vooruitgang in Discussie (Innovation for Ever: The Belief in Technical Progress in Discussion). Amersfoort: de Horstink (Dissertation).

Thompson, P. B., \& Hannah, W. (2008). Food and Agricultural Biotechnology: A summary and analysis of ethical concerns. Advances in Biochemical Engineering/Biotechnology, 111, 229-264.

Treaty of Rome. (1957). http://ec_europa.eu/economy_finace/emu_history/documents/treaties/rometreaty2. pdf

van Bruchem, C., \& Visser, C. (2004). Boeren voor Morgen: Landbouwbeleid en Christelijke Politiek (Farming for Tomorrow: Agricultural Policy and Christian Politics). Amsterdam: Buijten and Schipperheijn.

van den Berg, H., \& Nijhoff, R. A. (Eds.). (2009). Bio-energie: Natuurlijk beter? (Bio-energy: Naturally Better?). Amersfoort: Wetenschappelijk Instituut van de ChristenUnie.

van der Ban, A. W. (1983). De rol van voorlichting en voorlichtingskunde in de samenleving (The Role of Information and Information Science in Society). Farewell Speech at the Agricultural University Wageningen. Unpublished manuscript available at Wageningen University.

van der Laan, J. M. (2004). Temptation and seduction in the technological milieu. Bulletin of Science Technology and Society, 24(6), 509-514.

van der Ploeg, J. D. (1999). De Virtuele Boer (The Virtual Farmer). Assen: Van Gorcum.

van der Ziel, T. (2008). Verzet en Verlangen: Het Platteland in de Greep van MKZ en Stedeling (Resistance and Desire: the Countryside in the Grip of FMD and Townsman). Kampen: Stichting IJsselacademie. 
van Otterloo, A. H. (2000). Voeding in Verandering (Food in change). In J. W. Schot, H. Lintsen, \& A. Rip (Eds.), Techniek in Nederland in de Twintigste Eeuw, Deel III: Landbouw en Voeding (pp. 237-247). Zutphen: Walburg Pers.

VanderBurg, W. H. (2004). The autonomy of technique revisited. Bulletin of ScienceTechnology and Society, 24(6), 515-517.

Visser J (2010). Down to Earth, Dissertation, Wageningen University, Wageningen.

Weis, T. (2010). The accelerating biophysical contradictions of industrial capitalist agriculture. Journal of Agrarian Change, 10(3), 315-341.

Williams, N. M. (2008). Affected Ignorance and animal suffering: Why our failure to debate factory farming puts us at moral risk. Journal of Agricultural and Environmental Ethics, 21, 371-384.

Woodhouse, P. (2010). Beyond industrial agriculture? Some questions about farm size, productivity and sustainability. Journal of Agrarian Change, 10(3), 437-453.

Young, P. (1988). Ellul on technological forecasting. Futures, 20(2), 194-197. 